\title{
MOLECULAR BIOLOGY AND GENETIC MECHANISMS IN THE PROGRESSION OF THE MALIGNANT SKIN MELANOMA
}

\author{
Sofija Pejkova ${ }^{1}$, Gjorgje Dzokic ${ }^{1}$, Smilja Tudzarova-Gjorgova ${ }^{1}$ Sasho Panov $^{2}$ \\ ${ }^{1}$ University Plastic and Reconstructive Surgery Clinic, Medical Faculty, University Ss. Cyril and \\ Methodius, Skopje, R. Macedonia \\ ${ }^{2}$ Molecular Biology and Genetics Laboratory, Faculty of Natural Sciences and Mathematics, University \\ Ss. Cyril and Methodius, Skopje, R. Macedonia
}

Corresponding Author: Ass. Dr. Sofija Pejkova, Address: University Plastic and Reconstructive Surgery Clinic, Medical Faculty, Ss. Cyril and Methodius University, Vodnjaska 17, MK-1000, Skopje; e-mail:pejkova@gmail.com

\begin{abstract}
Malignant skin melanoma is a tumor deriving from transformed skin melanocytes as a result of complex interactions between genetic and environmental factors. This melanoma has a potential to metastasize early and very often it is resistant to the existing modalities of the systemic therapy. As in any other neoplasms, certain types of melanoma may skip certain stages of progression.

The progression from one stage to another is accompanied by specific biological changes. Several key changes in the melanoma tumorogenesis influence the regulation of the cell proliferation and vitality, including the RAS-RAF-ERK, PI3K-AKT, and $\mathrm{p} 16^{\mathrm{INK} 4} / \mathrm{CDK} 4 / \mathrm{RB}$ pathways. A key role in the dissreguarity of the RAS-RAF-ERK (MAPK) pathway in the malignant melanoma development have been demonstrated by many studies. To date, the molecular genetic alterations during melanoma development have been partially known. In the pathogenesis of the malignant melanoma, there are mutations of various genes such as NRAS, BRAF, and PTEN and mutations and deletions of CDKN2A.

In the past years, great advance has been made in the insights of the molecular aspects of the melanoma pathogenesis. However, this field yet poses a challenge to discover new details about the melanoma molecular characteristics. The research results are focused towards the improvement of the melanoma patients prognosis by introducing personalized targeted therapy.
\end{abstract}

Keywords: melanoma, NRAS, BRAF, and PTEN, prognosis factors

\section{Introduction}

Malignant skin melanoma is a tumor deriving from the transformed genetically altered skin melanocytes as a result of complex interactions between genetic and environmental factors. The melanocytes located in the basal epidermal layer synthesize and transfer the pigment melanin to the surrounding keratinocytes and thus protect these cells from the harmful effect of the UV rays [1]. A rapid increase of malignity has been observed in melanoma. The latest epidemiological analyses have shown that melanoma incidence is higher than the rest of the skin malignity $[2,3]$. The malignant skin melanoma has a potential to metastasize and very often it is resistant to the existing modalities of the systemic therapy. This is the reason due to which the increased incidence is related to the high mortality of patients with this disease.

\section{Progression of Melanoma}

According to the results from the clinical and histological studies, the melanoma development and progression are defined in several stages: stage 0 , normal melanocytes; stage 1 , congenital and acquired nevus in presence of 
structurally normal melanocytes; stage 2, dysplastic nevus with atypical architecture; stage 3, melanoma in situ (MIS) and radial stage of growth (RSG), i.e. primary melanoma without metastatic competency; stage 4, vertical stage of growth (VSG), i.e. primary melanoma with metastatic competency, and stage 5, metastatic melanoma. As in any other neoplastic system, certain types of melanoma may skip certain stages of progression [5].

The progression from one stage to another is accompanied by specific biological changes. The transition from a mature melanocyte while forming a nevus is characterized by the disorder of the cell-cell cross-talk between the melanocytes and keratinocytes, which results in exiting of the melanocytes from the keratinocyte regulatory mechanisms. The nevus cells are characterized by the limited proliferation and they do not have significant chromosome aberrations. Nevus can develop not as a result from a certain stimuli only, but also because of the loss of the keratinocyte control mechanisms over the melanocytes. The progression from melanocytic to dysplastic nevus or RGP melanoma is most probably accompanied by the occurrence of the genetic aberrations. The cells are cytologically atypical and can separate from the basal membrane without the apoptosis process, and the whole lesion is architecturally atypical. The lesion cells with RSG in vitro have biological properties with medium benign to malignant features. The primary melanoma with VSG have nodular changes that penetrate deeply into the dermis. The primary melanoma with VSG are especially aneuploidy. Biologically, the cells of these melanoma types are characterized by relative plasticity, while some of them have metastatic competency. There is a high level of genetic instability and phenotypical plasticity in the metastatic cells depending on the environment and all selective factors that affect the cells $[5,6]$. The metastatic cells are quite mobile and independent of the growth factors and have acquired capacity for invading other tissues and organs.

\section{Risk Factors in Melanoma}

Similar to the most types of cancer, melanoma has two types of risk factors, important for its development. These factors are typical for the host and the environment. Epidemiological studies have identified the host risk factors, important for melanoma development. These include family history, changes in the gene susceptibility extent to melanoma, nevus number and type, skin type, and pigmentation [7]. Melanoma occurs more frequently in persons with light complexion, blue or green eyes, red or blond hair, lots of sunspots, and in persons that react to light by being sunburnt rather than getting suntanned.

UV radiation is the most important environmental factor for melanoma development. Occasional repetitive exposure to sunlight from childhood has been epidemiologically proven as the main reason for melanoma development. It has been experimentally proven that UVB rays, which are a small component of the sunlight that reaches the earth, are the cause of skin cancer in animals. UVB rays can cause DNA damage, especially of the cyclobutane pyrimidine dimers (CPD) and photoproducts that can cause mutations of epidermal cells, that leads to the development of cancer [4-6].

It is known that UVB rays regulate the gene expression through intracellular pathways for signal transduction, which can contribute to the development of skin cancer during the stage of the tumor progression. Further, it has been experimentally demonstrated in animals that the local or systemic action of the UVB rays causes suppression of immune reactions and induction of antigen tolerance. It is believed that these three effects of the UVB rays on the skin are the causes of skin cancer development in humans [8].

UVA rays present the major part (approx. 95\%) of the UV light that penetrates the earth's surface and many epidemiological studies have confirmed that these rays can be the cause of benign and malignant skin tumor development. UVA rays through the epidermis penetrate deep into the dermis. The cell damage by the UVA rays occurs primarily through the formation of the reactive oxygen species (ROS). After the exposure to UVA rays, molecular oxygen, $\mathrm{H}_{2} \mathrm{O}_{2}$ (hydrogen peroxide), superoxide, and hydroxyl free radicals are formed. The interactions among them may cause damage to the cell proteins, lipids, and saccharides. UVA rays may directly cause structural damage to the DNA where 8- 
oxo-guanin is the most common lesion that inhibits DNA reparation, while at the same time, it has an effect on various pathways for signal transduction and leads to disorder of the immune system processes [9].

\section{Pathways Relevant to the Cancer Biology}

Several key changes of the melanoma tumorogenesis influence the regulation of cell proliferation and vitality, including the RASRAF-ERK, PI3K-AKT and p16 ${ }^{\mathrm{INK} 4} / \mathrm{CDK} 4 / \mathrm{RB}$ pathways $[10,11]$. There are many studies that have proved that the RAS-RAF-ERK (MAPK) pathway plays a key role in the malignant melanoma development [11-14].

\section{RAS signaling pathways}

The family of $R A S$ genes is one of the most commonly activated oncogenes in the human cancer development. RAS proteins are small monomer GTP-ases that have an important role in the process of the growth signals transduction from the cell surface to the nucleus. By activating certain mutations in RAS, the cell transformation is promoted through the effect of the growth factors of the independent stimulation of the cell proliferation and the survival. There are three genes identified in humans: HRAS, $N R A S$, and KRAS. As in other GTP-ases, the functions of the RAS proteins are regulated by GDP-GTP binary switches. The extracellular signals are received by receptors, bound to the cell membrane, such as the receptors bound to the $\mathrm{G}$ protein (GPCR) and the tyrosine kinase receptors (TKR). These receptors activate the guanine factors for exchange that cause transitory activation of RAS. The activated RASGTP alleviates the binding and activation of the effectors. The RAS signaling is interrupted by RAS GAP-mediated stimulation of hydrolysis of GTP into GDP and frees itself from the bound effector [15]. The most common mutations of RAS in tumors occur at the critical RAS regulation points. Single-nucleotide mutations at codons 12, 13, 59, and 61 completely interrupt the GAP-induced GTP hydrolysis of RAS. Unlike the normal RAS, the oncogenic RAS protein remains constitutionally in the active GTP-bound form. Therefore, the properties for transformation of the oncogenic RAS are based on continuing the activation of its effectors [16].

There are three main RAS effectors, RAF kinase, RAL-GEF, and PI3K, which bind to the same region of RAS-GTP, i.e. the domain 3240. All of these effectors increase their in vivo activity after binding with RAS [17].

\section{RAS-RAF-ERK signalization}

The best known RAS stimulated pathway, which is directly related to the actions that promote growth, begins with the activation of the serine/threonine kinase of the RAF family. There are three members of the RAF class: ARAF, BRAF, and CRAF. The latest studies have shown that RAS interacts with the aminoterminal part of RAF, located in the cytoplasm as part of the 14-3-3 protein, which is an essential cofactor of the RAF kinase action [18]. This interaction causes conformational changes in RAF by which one or more of the phosphorrylation and stabilization residues of the new catalytic active RAF are un/masked. After these conformational changes, RAS binds to the plasma membrane. The RAF-RAS binding is transitory and the moment it binds to the membrane the RAF action becomes independent from RAS and is no longer dependent on the dominantly negative RAS mutations. The phosphorylated RAF activates a series of kinases in cascade, which through the increase of the low cell signals modulates the activity of several cytoplasmic and nucleus factors [19]. During this activity, the signals transferred to the nucleus define the activation of the transcription factors, such as the members of the Ets family [20]. These transcription factors influence the expression of the specific genes responsible for the proteins included in the control of the cell proliferation and/or differentiation [17].

\section{RAS-PI3K-AKT signalization}

Another well-known RAS effector is PI3K, with a role in the cell proliferation and survival processes. PI3-kinases are lipid kinases that participate in the process of phosphorrylation of 3'-OH position of inositol phosphorlipids. RAS-GTP may bind and activate the catalytic subunits of this enzyme which produces PI P3 (phosphatidylinositol tri-phosphate) through phosphorylation of PI P2 in 3-position. PI P3 acts directly as second messenger, binding 
itself to cytoskeleton protein kinases and thus makes modulation of their activity through conformational changes and/or translocation of the membrane. PI3K class I is made of $110 \mathrm{kDa}$ catalytic subunits and one $85 \mathrm{kDa}$ regulatory subunit. These are activated by RAS or RTK. The catalytic subunit p110 contains RBD (a domain that binds to RAS), to which RAS-GTP is binded. The catalytic subunit p85 has a binding and kinase domain, too. The main downstream goal of PI3K is the serine/threonine kinase AKT (or PKB). In mammals, there are three different isoforms of three different AKT (AKT1, 2, 3). This protein regulates the extracellular growth signals using the phosphatidylinositol-phosphate (PIP3) as one intracellular second messenger. Under the action of the growth factor signals, the intracellular level of PIP3 increases, which leads to phosphorylation of AKT, which promotes the progression of the cell cycle and inhibits apoptosis. PTEN is a negative regulator of PI3K-AKT pathway [21]. PTEN regulates the PIP3 levels, inactivates the results from PIP3 accumulation, makes hyperphosphorylation of AKT and improves cell survival and cell proliferation [22]. PI3K-AKT pathway is hyperactive in melanoma. It must be noted that the increased levels of phosphoAKT has a negative correlation to the survival of melanoma patients [21].

\section{RAS-RAL signalization}

Another class of RAS effectors is the GEF family (RalGDS) which is an activator of the small monomers, RAL GTP-ases. In RAL, there is an interaction with Cdc42 and RACGAP. Rho, RAC, and Cdc42, which are members of another monomer family, G proteins with an important role in remodeling of cytoskeleton and activation of the kinase action that regulates the activity of various transcription factors. The signaling activity of the RAS GTP-ases begins not only through the action of the direct effectors, but through the activation of other GTP-ases, especially other members of the RAS sub-family (for e.g. Rap) and members of the Rho subfamily (for e.g. RhoA, Rac1, and cdc42). This hierarchical network among various isoforms of RAS is partially controlled by the interactions of GEF, GAP, and the downstream effectors. For instance, Ra1GEF are especially important for the process of RASmediated transformation. Ra1GEF, as well as Ra1GDS, link the RAS signalization for activation of the small GTP-ases, Ra1A, and Ra1B. In humans, the RAS mutant effector branch activates Ra1GDS, after which they enter the process of cell transformation [23].

\section{Other Effectors in RAS signaling pathway}

Other potential effectors are AF-6, protein kinase C-zeta (PKC-zeta), and Nore1. RAS uses the AF-6 effector for modulation of the intracellular binding and communication. PKCzeta shows RAF homology. The recent studies have shown that PKC-zeta may activate the RAS pathway regardless of RAS [24]. It has to be also mentioned that recent studies have discovered members of RASSF (RAS association domain family protein) gene family that have effect on tumor suppressive genes. The loss of expression of Nore1 (novel RAS effector 1) and RASSF1, members of the RASSF gene family, are found in various types of cancers [25]. The interaction between RAS and Nore1 has an effect on the apoptosis regulation [26].

\section{RB and $\mathbf{p 5 3}$ pathways}

In mammals, the INK4A-ARF locus decodes two different proteins, p14 ${ }^{\mathrm{ARF}}$ and $\mathrm{p} 16^{\mathrm{INK} 4 \mathrm{~A}}$, whose actions have an effect on the control of the cell cycle and tumor suppression, and are included in two different protein-protein interactions: $\mathrm{p} 16^{\mathrm{INK} 4 \mathrm{~A}}-\mathrm{RB}$ и $\mathrm{p} 14^{\mathrm{ARF}}-\mathrm{p} 53$. These two gene products with the transcription process are initiated by various promotors and decode in two different frameworks: $\mathrm{p} 16^{\mathrm{INK} 4 \mathrm{~A}}$, which refers to INK4A, and p14 ${ }^{\mathrm{ARF}}$, which refers to ARF. INK4A positively regulates the tumor suppressor RB through CDK4 suppression, while the ARF protein forms a complex with HDM2 and p53 and blocks their outing from the nucleus, leading to p53 stabilization and its activation in the nucleus [27].

\section{Mutations in the Oncogenes and Suppressor Genes in Melanoma}

To date, the molecular genetic alterations during melanoma development have been only partially known. In the pathogenesis of malignnant melanoma, there are mutations of various 
genes, such as NRAS, BRAF, and PTEN, and mutations and deletions of CDKN2A. Selected genetic alterations in malignant melanoma are presented in the Table 1 [25].

Table 1

Genetic alterations in melanoma

\begin{tabular}{llll}
\hline Gene Type & Gene & Alteration Frequency in Melanoma & Alteration Type \\
\hline \multirow{4}{*}{ Oncogenes } & BRAF & $50-70 \%$ & Mutation \\
\cline { 2 - 4 } & NRAS & $15-30 \%$ & Mutation \\
\cline { 2 - 4 } & AKT3 & $43-60 \%$ & Expression \\
\cline { 2 - 4 } & CCND1 & $6-44 \%$ & Amplification \\
\hline \multirow{3}{*}{$\begin{array}{l}\text { Tumour- } \\
\text { suppressors }\end{array}$} & CDKN2A & $10-16 \%$ & Amplification \\
\cline { 2 - 4 } & PTEN & $20-70 \%$ & Deletion or Mutation \\
\cline { 2 - 4 } & APAF-1 & $40 \%$ & Deletion or Mutation \\
\hline
\end{tabular}

Modified by Dohmem et al., 2007 [61]

RAS: RAS genes are among the commonest mutated genes in human cancers with various range of NRAS, HRAS, and KRAS mutations. In human melanoma, the commonest are NRAS mutations (5-36\%), where $90 \%$ of these mutations are located in code 61 [28-30]. HRAS and KRAS rarely mutate. NRAS mutations are found in $10 \%$ of nevus [31, 32] and in $81 \%$ of congenital nevus [26-32], while these lesions do not exist in BRAF mutations [33]. Albino and Fountain have shown that there are NRAS alterations in $24 \%$ metastatic and $12 \%$ primary metastatic melanoma tumors, while other authors reported higher frequency of these mutations in primary tumors and suggest that these mutations influence the disease progression and metastases development [34]. Results from other studies present that there are NRAS-gene mutations in $33 \%$ of primary and $26 \%$ of metastatic melanoma tumors [35, 36]. The activated NRAS mutations, in correlation to the sun exposure, are found in nodular melanoma tumors [3740]. The presence of NRAS mutations in melanocyte lesions and lesions in radial growth phase (RGP) or melanoma in situ, suggest that the NRAS activation in the early phase of melanoma development [35, 36].

$\boldsymbol{R A F}$ : The commonest mutated component of the RAS-RAF-ERK pathway in melanoma is BRAF. BRAF mutates in $50-70 \%$ of melanoma cases, the most frequent mutation being the substitution of valine with glutamine acid in position 600 (V600E) [36, 41]. This mutation is found in $80 \%$ of benign nevus, while it is not present in uveal melanoma tumors [42]. The BRAF gene is found in chromosome 7q34 region, very often amplified in melanoma tumors [43].

PI3K: PIK3CA mutations are rarely found in melanoma tumors, i.e. in $1 \%$ of primary melanoma tumors and 3\% in metastatic melanoma tumors, without data for enforcement of any PI3K subunit in primary melanoma [44, 45].

AKT: The activation of $A K T$ is a potent oncogene for the set off of melanocyte transformation [46]. AKT3 is the main isoform found in melanoma. AKT3 locus is found in the DNA copy of melanoma, while selective activation of AKT3 is found in $40-60 \%$ of tumors [47]. The latest research have shown that the activetion of various AKT isotypes have an effect on the cell proliferation and survival. For instance, out of the three AKT isotypes, AKT3 is in strong correlation to the tumor progression, while targeted depletion of AKT3 causes apoptotic signalization [47].

PTEN: PTEN is another important element in the transduction signal disorder process in human melanoma. PTEN is a tumor suppressor candidate from the chromosome region 10q23-24, which is most often deleted in glioma and melanoma [48, 49]. Cytogenetic research show that the loss of 10q is often found in melanoma. PTEN decodes a protein which has an extensive homology and specificity to protein phosphatases, such as RAS, and enters pathways for apoptosis control through AKT. 
PTEN is a negative regulator of PI3K-AKT pathway. By AKT phosphorylation, it gains more properties, but the main property is antagonism to the apoptosis process. Some research have shown that the loss of PTEN leads to the apoptosis process disorder. In melanoma, the loss or altered expression of PTEN is found in 20$40 \%$ of tumors [21, 50], while there are rarely somatic mutations and homozygous deletions. Functionally, the ectopic expression of PTEN in PTEN-deficient melanoma cells may interrupt the phosphorylation of AKT, induce apoptosis, and suppress the growth process, tumorigenicity and metastases [51, 52]. Interestingly, NRAS and PTEN act mutually in melanoma, i.e. NRAS mutations and PTEN alterations in melanoma have mutually covering/overlapping actions [53]. On the other hand, $B R A F$ mutations and PTEN alterations coexist in same melanoma cell lines, which suggests that BRAF activation and PTEN loss may mutually activate $E R K$ and $A K T$ in melanoma [10].

c-KIT: Immunohistochemical studies show that the transition of benign nevus into primary or metastatic melanoma tumors comes from the progressive loss of $c$-KIT expression [54]. Some studies also prove the recurrent mutation of L576P in c-KIT. In 153 examined cases, Willmore et al. identified strong expression of $c$ KIT in 4 metastatic melanoma tumors, where L576P mutation with selective loss of normal allele was found in 3 of them. L576P is a GIST-associated mutation that binds to the juxta membrane domain, where the KIT cluster mutations are activated $[55,56]$. A study with 102 primary melanoma tumors reports that the mutation process is increased in cases with $c$ KIT presence, in $39 \%$ of the mucous, $36 \%$ acral, and $28 \%$ in melanoma tumors with chronically exposed skin to sun, but not in skin melanoma tumors that were not chronically exposed to sun. In $79 \%$ of tumors with mutations and 53\% with multiple copies of KIT there are an increased levels of KIT protein [57].

p16 ${ }^{\text {INK4A }}$ : Sporadic melanoma tumors and melanoma tumors with family history are associated with mutations, loss of heterozygosity and deletions of CDKN2A locus, factors that are especially important for normal progression of the cell cycle. The somatic inactivity of $C D K N 2 A$ ( $p 16^{I N K 4 A}$ and $\left.p 14^{A R F}\right)$ is very frequ- ently found in the melanoma cell lines [58]. Study results from metastatic melanoma tumors show that biallelic CDKN2A deletions are found in $45 \%$ and are associated with bad prognosis, while this fact emphasizes the importance of this locus in the disease progression [59].

The expression of $\mathrm{p} 16^{\text {INK4A }}$ is in negative correlation to the aggressive melanoma tumors. It must be pointed out that mutations of this locus are found in normal melanocytes, too, as well as in cells of benign nevus without signs of clinical or histological atypia [27].

P53 and p1 ${ }^{\text {ARF }}$ TP53 (p53 gene) mutations are involved in the pathogenesis of many neoplasms, but their role in the melanoma development has not been proven yet. TP53 mutations are rare in human primary melanoma and this is the reason why a correlation has not been confirmed between the restructuring of TP53 or altered expression of p53 protein and the melanocytic lesion progression. Nevertheless, some authors suggest that p53 may have a very complex role in the melanoma pathogennesis through its action of effector genes, such as HDM2, GADD45, and CIP1/WAF1 [27]. $A R F$ is considered to be predominantly positive regulator of p53 tumor suppressor through inhibition of HDM2. Therefore, ARF loss may be the cause of TP53 mutation shortage in melanoma tumors. However, it has been experimentally proven that ARF acts as a tumor suppressor through p53 sequence induction. According to the research with ARF- and TP53-deficient mice, there were no identical tumor phenotypes, ARF entered in interaction with various proteins, including E2F1, Myc, NF-B, and it may act independently of p53 biosynthesis in ribosomes, in DNA destruction, apoptosis, and autophagia [60].

\section{Conclusion}

Recently, considerable advance has been made in the insights of the molecular genetic alterations during melanoma development. However, this field yet demands a challenge to discover much more new details about melanoma molecular characteristics. The research is focused on mutations and other epigenetic and genetic alterations at particular genes which may be an important target for specific anticancer prevention and therapy in melanoma patients. 


\section{REFERENCES}

1. Azoury SC, Lange JR. Epidemiology, risk factors, prevention, and early detection of melanoma. Surg Clin North Am. 2014; 94(5): 945-62.

2. Boyers LN, Karimkhani C, Naghavi M et al. Global mortality from conditions with skin manifestations. J Am Acad Dermatol. 2014 ;71(6): 1137-1143.

3. Berwick M, Wiggins C. The current epidemiology of cutaneous malignant melanoma. Front Biosci. 2006; 11: $1244-54$.

4. Thrift AP, Whiteman DC. Can we really predict risk of cancer? Cancer Epidemiol. 2013; 37(4): 349-52.

5. DeVita VT. RS, Hellman S. Cancer: Principle and Practice of Oncology. 7th ed: Lippncott Williams \& Wilkins; 2004.

6. Iles MM, Bishop DT, Taylor JC, GenoMEL Consortium. The effect on melanoma risk of genes previously associated with telomere length. J Natl Cancer Inst 2014; 106(10). pii: dju267.

7. Tucker MA, Goldstein AM. Melanoma etiology: where are we? Oncogene 2003; 22(20): 3042-52.

8. Chang C, Murzaku EC, Penn L et al. More skin, more sun, more tan, more melanoma. Am J Public Health. 2014; 104(11): e92-9.

9. Svobodova A, Zdarilova A, Maliskova J et al. Attenuation of UVA-induced damage to human keratinocytes by silymarin. J Dermatol Sci. 2007; 46(1): 21-30.

10. Lee JH, Choi JW, Kim YS. Frequencies of BRAF and NRAS mutations are different in histological types and sites of origin of cutaneous melanoma: a meta-analysis. Br J Dermatol. 2011; 164(4): 776-84.

11. Liu J, Fukunaga-Kalabis M, Li L et al. Developmental pathways activated in melanocytes and melanoma. Arch Biochem Biophys. 2014; 563C: 13-21.

12. Carlino MS, Todd JR, Gowrishankar K et al. Differential activity of MEK and ERK inhibitors in BRAF inhibitor resistant melanoma. Mol Oncol. 2014; 8(3): 544-54.

13. Tomei S, Bedognetti D, De Giorgi V et al. The immune-related role of BRAF in melanoma. Mol Oncol 2015; 9(1): 93-104.

14. Conrad WH, Swift RD, Biechele TL et al. Regulating the response to targeted MEK inhibition in melanoma: enhancing apoptosis in NRAS- and BRAF-mutant melanoma cells with $\mathrm{Wnt} / \beta$-catenin activation. Cell Cycle. 2012; 11(20): 3724-30.

15. Rojas AM, Fuentes G, Rausell A et al. The Ras protein superfamily: evolutionary tree and role of conserved amino acids. J Cell Biol. 2012; 196(2): 189201.

16. Baines AT, Xu D, Der CJ. Inhibition of Ras for cancer treatment: the search continues. Future Med Chem. 2011; 3(14): 1787-808.

17. Gysin S, Salt M, Young A et al. Therapeutic strategies for targeting ras proteins. Genes Cancer 2011; 2(3): 359-72.

18. Martin-Liberal J, Larkin J. New RAF kinase inhibitors in cancer therapy. Expert Opin Pharmacother. 2014; 15(9): 1235-45.
19. Mandalà M, Voit C. Targeting BRAF in melanoma: biological and clinical challenges. Crit Rev Oncol Hematol. 2013; 87(3): 239-55.

20. Yajima I, Kumasaka MY, Thang ND et al. RAS/RAF/MEK/ERK and PI3K/PTEN/AKT Signali ng in Malignant Melanoma Progression and Therapy. Dermatol Res Pract. 2012; 2012: 354191.

21. Nogueira C, Kim KH, Sung H et al. Cooperative interactions of PTEN deficiency and RAS activation in melanoma metastasis. Oncogene. 2010; 29(47): 6222-32.

22. Scatolini M, Grand MM, Grosso E et al. Altered molecular pathways in melanocytic lesions. Int J Cancer. 2010; 126(8): 1869-81.

23. Jakob JA, Bassett RL Jr, Ng CS et al. NRAS mutation status is an independent prognostic factor in metastatic melanoma. Cancer. 2012; 118(16): 4014-23.

24. Rozenberg GI, Monahan KB, Torrice C et al. Metastasis in an orthotopic murine model of melanoma is independent of RAS/RAF mutation Melanoma Res. 2010; 20(5): 361-71.

25. Gray-Schopfer V, Wellbrock C, Marais R. Melanoma biology and new targeted therapy. Nature. 2007; 445(7130): 851-7.

26. Haydn JM, Hufnagel A, Grimm J et al. The MAPK pathway as an apoptosis enhancer in melanoma. Oncotarget. 2014; 5(13): 5040-53.

27. Witkiewicz AK, Knudsen KE, Dicker AP et al. The meaning of p16(ink4a) expression in tumors: functional significance, clinical associations and future developments. Cell Cycle. 2011; 10(15): 2497-503.

28. Conde-Perez A, Larue L. Human relevance of NRAS/BRAF mouse melanoma models. Eur J Cell Biol. 2014; 93(1-2): 82-6.

29. Wilson W, Merlino G. Flipping the phenotypic switch on novel antimelanoma differentiation strategy. Pigment Cell Melanoma Res. 2013; 26(6):791-3.

30. Leachman SA, Carucci J, Kohlmann W et al. Selection criteria for genetic assessment of patients with familial melanoma. J Am Acad Dermatol. 2009; 61(4): 677. e1-14.

31. Oikonomou E, Koustas E, Goulielmaki $M$ et al. BRAF vs RAS oncogenes: Are mutations of the same pathway equal? Differential signalling and therapeutic implications. Oncotarget. 2014; 5(23): 11752-77.

32. Kumar R, Angelini S, Snellman E, et al. BRAF mutations are common somatic events in melanocytic nevi. J Invest Dermatol. 2004;122(2): 342-8.

33. Bauer J, Curtin JA, Pinkel D et al. Congenital melanocytic nevi frequently harbor NRAS mutations but no BRAF mutations. J Invest Dermatol. 2007; 127(1): 179-82.

34. Albino AP, Fountain JW. Molecular genetics of human malignant melanoma. Cancer Treat Res. 1993; 65:201-55.

35. Demunter A, Stas M, Degreef $\mathrm{H}$ et al. Analysis of $\mathrm{N}$ - and K-ras mutations in the distinctive tumor progression phases of melanoma. J Invest Dermatol. 2001; 117(6): 1483-9.

36. Omholt K, Karsberg S, Platz A et al. Screening of Nras Codon 61 Mutations in Paired Primary and Metastatic Cutaneous Melanomas: Mutations Occur Early 
and Persist throughout Tumor Progression. Clin Cancer Res. 2002; 8(11): 3468-74.

37. Bradish JR, Cheng L. Molecular pathology of malignant melanoma: changing the clinical practice paradigm toward a personalized approach. Hum Pathol. 2014; 45(7): 1315-26.

38. Abschuetz O, Osen W, Frank K et al. T-Cell_Mediated Immune Responses Induced in ret Transgenic Mouse Model of Malignant Melanoma. Cancers (Basel). 2012; 4(2): 490-503.

39. Mar VJ, Wong SQ, Li J et al. BRAF/NRAS wildtype melanomas have a high mutation load correlating with histologic and molecular signatures of UV damage. Clin Cancer Res. 2013; 19(17): 4589-98.

40. Jiveskog S, Ragnarsson-Olding B, Platz A et al. Nras mutations are common in melanomas from sunexposed skin of humans but rare in mucosal membranes or unexposed skin. J Invest Dermatol. 1998; 111(5): 757-61.

41. Davies H, Bignell GR, Cox C et al. Mutations of the BRAF gene in human cancer. Nature. 2002; 417(6892): 949-54.

42. Cruz F 3rd, Rubin BP, Wilson D et al. Absence of BRAF and NRAS mutations in uveal melanoma. Cancer Res. 2003; 63(18): 5761-6.

43. Bastian BC, LeBoit PE, Hamm H et al. Chromosomal gains and losses in primary cutaneous melanomas detected by comparative genomic hybridization. Cancer Res. 1998; 58(10): 2170-5.

44. Curtin JA, Stark MS, Pinkel D et al. PI3-kinase subunits are infrequent somatic targets in melanoma. J Invest Dermatol. 2006; 126(7): 1660-3.

45. Omholt K, Krockel D, Ringborg U et al. Mutations of PIK3CA are rare in cutaneous melanoma. Melanoma Res. 2006; 16(2): 197-200.

46. Chudnovsky Y, Khavari PA, Adams AE. Melanoma genetics and the development of rational therapeutics. J Clin Invest. 2005; 115(4): 813-24.

47. Stahl JM, Sharma A, Cheung M et al. Deregulated Akt3 activity promotes development of malignant melanoma. Cancer Res. 2004; 64(19): 7002-10.

48. Held L, Eigentler TK, Metzler G et al. Proliferative activity, chromosomal aberrations, and tumor-specific mutations in the differential diagnosis between blue nevi and melanoma. Am J Pathol. 2013; 182(3): 640-5.

49. Wu H, Goel V, Haluska FG. PTEN signaling pathways in melanoma. Oncogene. 2003; 22(20): 311322.

50. Pollock PM, Walker GJ, Glendening JM et al. PTEN inactivation is rare in melanoma tumours but occurs frequently in melanoma cell lines. Melanoma Res. 2002; 12(6): 565-75.

51. Stahl JM, Cheung M, Sharma A et al. Loss of PTEN promotes tumor development in malignant melanoma. Cancer Res. 2003; 63(11): 2881-90.

52. Stewart AL, Mhashilkar AM, Yang XH et al. PI3 kinase blockade by Ad-PTEN inhibits invasion and induces apoptosis in RGP and metastatic melanoma cells. Mol Med. 2002; 8(8): 451-61.

53. Tsao H, Zhang X, Fowlkes $\mathrm{K}$ et al. Relative reciprocity of NRAS and PTEN/MMAC1 alterations in cutaneous melanoma cell lines. Cancer Res. 2000; 60(7): 1800-4.

54. Isabel ZY, Fitzpatrick JE. Expression of c-kit (CD117) in Spitz nevus and malignant melanoma. J Cutan Pathol. 2006; 33(1): 33-7.

55. Willmore-Payne C, Layfield LJ, Holden JA. c-KIT mutation analysis for diagnosis of gastrointestinal stromal tumors in fine needle aspiration specimens. Cancer. 2005; 105(3): 165-70.

56. Fukuda R, Hamamoto N, Uchida Y et al. Gastrointestinal stromal tumor with a novel mutation of KIT proto-oncogene. Intern Med. 2001; 40(4): 301-3.

57. Curtin JA, Busam K, Pinkel D et al. Somatic activation of KIT in distinct subtypes of melanoma. J Clin Oncol. 2006; 24(26): 4340-6.

58. Cachia AR, Indsto JO, McLaren KM et al. CDKN2A mutation and deletion status in thin and thick primary melanoma. Clin Cancer Res. 2000; 6(9): 3511-5.

59. Grafstrom E, Egyhazi S, Ringborg U et al. Biallelic deletions in INK4 in cutaneous melanoma are common and associated with decreased survival. Clin Cancer Res. 2005; 11(8): 2991-7.

60. Sherr CJ. Divorcing ARF and p53: an unsettled case. Nat Rev Cancer. 2006; 6(9): 663-73.

61. Dhomen N, Marais R. New insight into BRAF mutations in cancer. Curr Opin Genet Dev. 2007; 17(1): 31-9.

Резиме

\section{МОЛЕКУЛАРНА БИОЛОГИЈА \\ И ГЕНЕТСКИ МЕХАНИЗМИ \\ ВО ПРОГРЕСИЈАТА НА МАЛИГНИОТ МЕЛАНОМ НА КОЖАТА}

\section{Софија Пејкова ${ }^{1}$, Ѓорѓе Џокиќ ${ }^{1}$, Смиља Туџарова-Ѓоргова ${ }^{1}$ Сашо Панов ${ }^{2}$}

1 Универзитетска клиника за пластична и реконструктивна хирургија, Медицински факултет, Универзитет „Св. Кирил и Методиј“, Скопје

2 Лабораторија за молекуларна биологија и генетика, Природно-математички факултет, Универзитет „Св. Кирил и Методиј““, Скопје

Малигниот меланом на кожата претставува тумор кој потекнува од трансформираните генетски алтерирани меланоцити на кожата како резултат на комплексни интеракции помеѓу генетските фактори и факторите на околината. Малигниот меланом на кожата има потенцијал 
да метастазира и многу често е резистентен на постоечките модалитети на системска терапија. Како и кај секој друг систем на неоплазија, кај некои меланоми може да дојде до прескокнување на фазите во нивната прогресија.

Прогресијата од една кон друга фаза е придружена со специфични биолошки промени. Неколку клучни промени во туморогенезата на меланомот влијаат на регулацијата на клеточната пролиферација и виталност, вклучувајки ги RAS-RAF-ERK, PI3K-AKT и p16INK4/CDK4/RB патеки. Постојат многу студии кои докажуваат дека RAS-RAF-ERK (MAPK) патеката има клучна улога во развојот на малигниот меланом. До денес делумно се познати молекуларните генетски алтерации за време на развојот на меланомот. Во патогенезата на малигниот меланом се среќаваат мутации на различни гени, како што се NRAS, BRAF и PTEN и мутации и делеции на CDKN2A.

Во последниве години постои голем напредок во сознанијата за молекуларните аспекти на патогенезата на меланомот, но ова поле сѐ уште претставува предизвик за откривање нови детали од молекуларните карактеристики на меланомот. Резултатите од овие истражувања се насочени кон подобрување на прогнозата кај пациенти со меланом преку воведување персонализирана таргетирана терапија.

Клучни зборови: меланом, NRAS, BRAF и PTEN, прогностички фактор 